\title{
The United Kingdom Parents and Teachers Associations: A Lesson for Benin Parents Associations
}

\author{
Alidou R. Ibourahima Boro \\ University of Parakou, Parakou, Benin \\ Email: i.alidou@univ-parakou.com \\ Received 24 August 2015; accepted 10 October 2015; published 14 October 2015 \\ Copyright (C) 2015 by author and Scientific Research Publishing Inc. \\ This work is licensed under the Creative Commons Attribution International License (CC BY). \\ http://creativecommons.org/licenses/by/4.0/

(c) (i) Open Access

\section{Abstract}

Parents play an important role in their children's education. Their implication in the daily academic activities of their children can positively impact their results at the end of the year. The well-functioning of pedagogical activities could be more effective if parents and teachers join hands. So, parents must get involved in their children's school community by actively taking part in the Parents Associations (APEs). This paper examines the traditional roles of APEs in Benin and the main problems they are facing. These include inadequate funds raising policies, the absence of solid cooperation with school teachers and the mismanagement of the existing. The paper therefore makes some recommendations on how APEs can be reorganized to better serve school communities using good examples from PTAs of United Kingdom.

\section{Résumé}

Les parents jouent un rôle important dans l'éducation de leurs enfants. Leur implications dans les activités académiques quotidiennes des enfants peut positivement impacter leurs résultats de fin d'année. Les activités pédagogiques pourront être plus efficaces et prometteuses si Enseignants et parents se donnent la main. L'implication active des parents dans le fonctionnement de l'école est donc indispensable. Cet article examine le rôle des Associations des Parents d'Elèves au Benin et les maux qui minent leur bon fonctionnement. Ces maux ont pour noms, mauvaise gestion, mauvaise politique dans la recherche des financements, absence de solide coopération entre elles, les l'école d'une part et entre elles et les enseignants d'autre part. L'article propose enfin des solutions pour une gestion participative de ces Associations et fait des recommandations se basant sur l'expérience de la Grande Bretagne, sur la manière dont elles peuvent s'y prendre pour être plus efficacespour mieux servir la communauté.

\section{Keywords}

Parents Teachers Association, Schools Development, Children Education-Management 


\section{Mots Clés}

\section{Associations des Enseignants et Parents d'Elèves, Gestion, déVeloppement des Etablissements}

\section{Introduction}

Many researchers have already pointed out the significant role parent's play in their children's schooling. In their common works they think that when parents are involved in their children's education, their children perform better academically and socially [1] [2]. In Benin schools are organized in such a way that each school's parents create association to better follow the evolution of their children in school as well as the performances and academic results of the kids. The parents associations are social groups composed of students' parents who decide to work for the well-being of the school community they represent. For Abdullah [3], parents and teachers foster mutual understanding and cooperation. You can find such associations from nursery schools to universities in Benin. They even have recently created a Federation at National Level.

The research finds out that in most French speaking countries people talk about Parents Associations known as APEs while in the English countries people talk about Parents Teachers Associations also referred to as PTAs. For me the last denomination seems to be more accurate because if we want to list the main actors of a school apart from the learners, we do have the parents and the teachers among which the school staff comes from. In Benin and United Kingdom private and public learning institution you find APEs and PTAs. PTAs can contribute each with its specificities to conflicts resolution, to the well-functioning of the schools and can help schools raise funds for their sustainable development. This main concern of this paper based on some reports and articles from scholars is as follows: Considering its undeniable role and its social impacts on the well-functioning of schools and education, how Parents Associations can be reorganized and kept on assisting schools in order to ensure good education to their kids. I will first stress on the importance of parents and teacher for a child schooling. Then based on the role and the structures of both PTAs and APEs, I will suggest some key actions to APEs that could allow them to be more democratic and then effective.

\section{Benin Parents Associations}

Most of Benin APEs are created in conformity with the 1st July 1901 Universal Law giving the right to people to create and animate associations and organization for the well-being of their community. As I said above, in every single school in Benin from nursery school to university, no matter it is private or public, there are APEs. The main objective of those associations is to help the schools in any kind of difficulty. It will face and contribute to establish a good climate of work between the school actors. Each association is managed by two important bodies: the National Assembly and the Executives.

\subsection{The National Assemblies}

They are Supreme Organs where decisions are taken. They are made of all the active members of the association who meet once a year for an ordinary meeting or extraordinary meet on the demand of the executive. Members of the executive are elected by the National Assembly for a 5-year term or less according to the Article of Associations.

\subsection{The Executives}

They are the operational organ of the association. Members of the executive take care of the association's daily affairs. They annually report to the National Assembly and received instructions from for future actions.

The reality with Benin APEs

Almost all the Benin Parents Associations are well organized and well-structured with good and positive ambitions for education. But the reality is that some of the Associations become the patrimony of group of people who instead of using the raised funds for the school development use them for their own purposes. Some are presidents for decades though they no more have their children in the school they are elected member of APE. Other refuses to organize annual meeting to report to their constituents about their actions. Another group refus- 
es to organize election and reign as kings and so on. The list of mismanaging acts is long and cannot be mentioned here. The situation is in a condition that the main objectives are put aside for personal interests. This constitutes a great loss of profit for the whole school system. As far as money raising is concerned, it does not derive from the organization of events and cultural activities.

The ruling funds come directly from parents pocket in a form of subscription sometimes higher than the normal school fees. Because of lack of report and transparency, some parents refuse to participate as a result the association is not able to realize its activities correctly. From the above realities it clearly appears that actions have to be taken to readdress the issues of school associations.

\section{The United Kingdom Parents Teachers Associations}

From the day your child starts at any British school you can become member of the PTA then he will benefit from resources coming from money raised by parents. The United Kingdom schooling system Parent Teacher Associations are very important. Parents, teachers and school staffs join forces to improve the school daily management. The main role of those PTAs is to develop and maintain good relations between actors of the school community for a common purpose which is the education of the children.

Most of the British join the PTAs to benefit from the enormous services they provide. Some PTAs may help parents who are very busy with their professional activities. Other joins because PTAs are group of solidarity where parents and teachers can bring their support to family with financial problems. In schools without school buses PTAs buy buses for their children to enjoy going to school.

\subsection{Functions of the PTAs}

Parent Teacher Associations are forum of suggestions and exchange among school community members. They plan regular meetings to discuss and find solutions to issues related to their institution. For such meetings Board Governors plan an important role. They coordinate action and concretize outcomes of the meetings. PTAs can sometimes bring to discuss the school curriculum and syllabus under which their children are being taught and teachers and make some suggestions to the school staff. PTAs can be associated to the school enrolments. Oniyangi [4] confirms that when talking about PTA s in Nigeria he wrote that PTAs assists in improving the enrolment of the schools in their communities; helps in maintaining disciplines in the schools; ensure smooth co-existence, understanding and cooperation between the school and the community. In the same vein, Abdullahi [3] also reported that the PTA complements governments' efforts in the provision and maintenance of infrastructures in the schools.

\subsection{Executive Branch and Money Raising}

Most of the United Kingdom PTAs are ruled by executive committees for one year term. Contrary to PTAs; APEs members are elected for five years. APEs do not have specific date for annual meetings. AGs as they call them are organized according to the will of the Executives. Some even refuse to call for General meetings. This behavior of some Executives is source of the confiscation of popular power and has to stop. Opposed to APEs, PTAs hold their annual general meeting in September, at the start of the school year. The executive committees are generally made of ordinary members with at least one and often two, parents from each class. Their job is to pass on information from the PTA to other parents in their child's class. PTA committees usually meet once a term and set up smaller working groups to organize individual events. Most PTAs raise money through events. They often hold one main event each school term-for example, a Christmas fair in the winter, a quiz in the spring, and a summer fair. Other PTA events include school uniform sales, discos, firework displays, international evenings and many more. They're always looking for new fundraising ideas.

\section{Necessity for Benin APEs to Learn from UK PTAs}

From what have said above the survival of Benin Parents Associations depends on good examples they take and implement. As in the United Kingdom, the idea behind the creation of the Benin APEs was to establish strategies, ways and means to raise money and contribute to their children school development. Part of the raised funds is supposed to be used to pay part time teachers and contribute in some pedagogical and extra activities of the schools. As you see this is a noble mission. But, it is noticed that some of the associations misuse the raised 
funds. Elections become more political than social. The APEs which are elected on political basis neglect parents and schools needs and sometimes are far from the main established objectives. This is not good. Apart from that the fact that the APEs do not include teachers in the committee does not help them a lot in having information about the performances of their kids. These are some of the reason why I am recommending them to learn from PTAs.

- Actors of a school system being both parents and teachers, it would be good to start changing from APEs to PTAs in order to include teachers in the Association. This could help parents and teachers to be more and more in contact to better serve the community. As Hicks [5], Sammons, Hillman and Mortimore [6] and Cotton and Wikelund [7] in their various studies that many benefits are accrued for the school system, the parents and teachers when they all are involved in the school activities. Parents can easily follow the evolution of their children through the information they get from the administration and the teachers. This could create an atmosphere of mutual understanding. Putting both Teachers and Parents in the Association could strengthen open discussions which could leads to the resolutions of internal conflicts.

- PTAs easy communication between Parents and Teachers on children evolution and behavior at school I believe that by adopting PTAs form of Association parents could easily get information about the behavior of their kids. It would be easy for them to get information on how their kids behave and could start thinking of solutions from home.

- APEs should also learn from UK PTAs technics of money raising for the benefit of the school and the students. They could as UK PTAs organized cultural events such as musical concerts, charity actions. Oniyangi [4] stated on the same vain that the school should make itself not only accessible to the community when community development activities are organized but also participate fully whenever called upon to do so. Those actions could increase the number of participants then more funds to earn. Apart from the organizations of events and I suggest that APEs to take over the organization of the students so called cultural days where instead of profitable and intellectual activities they concentrate on destructive and nonsense ones. Parents Association should take this kind of occasion to help the school raising fund and work for its reputation.

- The promotion of good governance must be a must for Benin APEs.

Taking into account the role and the place of Education nowadays, such associations should be places of good governance and good management. Elections have to be regularly organized and executives' terms have to be reduced and alternative must be promoted.

For all this to be true, it would be important for APEs to integrate the following charts in their articles of association.

- Constitution

From the constitution of the APEs the purposes must be clearly defined based on the Ministries of Education regulations regarding Parent Teacher Associations.

- Aims of the News Associations

News aims are to be set out they should include:

- Fostering positive relationships between the school and families pertaining to the well-being of the school community (students, parents, Teachers, staff and faculty)

- Affording the study and discussion of all matters relating to the welfare of the children and to support and enrich teaching and learning experiences, recognizing that the Head of School is the responsible authority in the school.

- Organizing fund-raising activities to support the resources of officially rec organized not for profit organizations, charities and schools who are in need.

The duties and responsibilities of the PTA are should be clear and well known by all the actors. AS duties and responsibilities I suggest the following:

- Communication and cooperation between the school communities to support effective plans that could help to get good results at the end of the year.

- To purchase only goods or services to support officially recognized not for profit organizations, charities and schools within the framework of community service projects

- To participate and support celebratory days in the school.

AS far as the different organs are concerned there should be three main units that would make up the PTAs: 


\subsection{General Committee Made up of the School Administrators, Teachers, and Parents of the School}

The General Committee will meet every academic year before the end of September since Benin Schools generally open door in October. The first General Committee will be invited by the Executive Board. Attendance at the General Committee must be four times that of the number of members who will sit on the Executive Board. If there are not enough members present at the General meeting, then another meeting will be called within 30 days, and voting will take place, at which time a number of members present will not be a factor for voting. The General Committee meeting place, purpose of the meeting, date and time will be notified 15 days in advance, and will be included on the school website if it exists, and PTA notice board. Members of the student council are able to participate at the General Committee but as an observer. At that very first meeting, the previous year's PTA budget will be presented and handed-over to the new Executive Board in the presence of the General Committee Chair. A report will be presented to the new Executive Board and School Administration for any spending from the previous year's budget that cannot be accounted for.

\subsection{Executive Boards}

Elected members of the board must only serve for a full academic year and retire at the General Committee Meeting at the beginning of a new academic year. This would avoid the confiscation the power and promote democracy in the APEs. The Executive should also include the school principals in order to easy administrative affairs. Representatives from the Student Council can be invited to Executive Board meetings if relevant. The students will not have voting rights. All members of the Executive Board will meet within two weeks of the General Committee meeting, and assign the roles of the members. If a member leaves the Executive Board during a session, the Board will appoint a replacement from its existing members. The Executive Board would have the following role rights and responsibilities:

- The Executive Board works for the PTA, all decisions taken are planned and carried out with the cooperation and collaboration of the school administration.

- Meeting must be held once per month, but can be held more frequently as needed.

- The agenda must be shared electronically at least 7 days prior to the any meeting and distributed to all members by the President of the Executive Board.

- If the President is not at a meeting, the Deputy President will act in his/her place.

- The Treasurer will keep track of all incoming and outgoing funds. Once a semester the incoming and outgoing funds of the PTA will be published on the PTA notice board and school website.

- The secretary will keep a track of all minutes and decisions taken by the PTA and share the meeting minutes with all members of the Executive Board within 7 days. After the Executive Board approves the minutes, they will be posted on the school portal.

- All minutes will be filed in an official Ministry notebook and signed off by all committee members present.

- All communications with outside agencies or to the school community, budgetary spending and tasks will be made in coordination with the Head of School and Principals.

- The charities that the Executive Board works with must be official, legal charities and in line with the Minis try of Education regulations and approvals. The Head of School must approve the list of charities that the Executive Board wishes to work with and any changes that wish to be made must be voted on at the Executive Board meetings and then approved by the Head of School.

- If an Executive Board member has an unexcused absence for more than 3 meetings

- Action to be taken for the next meeting will be decided upon

\subsection{Auditing Committee}

The auditing committee would be made up of one parent, and one teacher and one staff member to encourage transparency'. Two weeks after the General Committee, their first meeting will be held, and they will choose a Chair for the committee. All members will serve for a full academic year and retire at the General Committee Meeting in the beginning of the next academic year.

The auditing committee role is to provide an audit of the PTA budget. The Auditing Committee will meet once at the end of each semester and provide a written report to the Executive Board with an audit of the budget. 
The final audit will happen in the last week of school and a report will be provided to the Executive Board before the last day of school. The auditing committee will not be a member of the Executive Board and may not attend regular meetings.

\subsection{APEs Budget}

Education being the key factor for any development we are all ready to do everything we can for our children education. But APEs should not force parents to pays subscription as it is in some Benin Schools. They may raise funds through social, cultural, sporting events and activities. Parents cannot be forced to make donations for any event or activity or pay for activities or events that are part of the normal course of the school day. All money needs to be deposited in a bank account in the name of the school concerned. Withdrawals can be made from the account with the signatures of two parties: the President or the Deputy President if he/she is not available and the Treasurer. And all monies spent and received should be documented by official receipts that have serial numbers attached to them. These receipts should have carbon copies and should be stamped using the official school stamp. The receipt numbers and money received or spent should be recorded into the Executive Board minutes and decisions notebook and budget book. All money spending needs to be approved by the majority of the Executive Board. In case of a tied vote the President's vote will decide.

This is my contribution for Benin APEs to become more effective. I believe that if associations could make the above suggestions be part of the Association Deeds, it may completely change the perception of the population about their management.

\section{Conclusion}

The role of Parents Association is widely recognized. PTAs are performing important roles in schools. They contribute a lot in the well-functioning of schools and help to maintain a peaceful atmosphere in the community. The fact that Parents Associations contribute to funds raising helps the school to solve its daily problems. The main problem with Benin APEs is their inactivity, the lack of democracy in some of them and the absence of innovation and good initiatives. APEs should learn from PTAs, especially from PTAs of the United Kingdom. I do agree that it won't be easy to quickly change behavior but we should persevere and take the decision to change. Based on the papers findings, I make some recommendations on how to strengthen the roles of the APEs and enlighten their actions for the development of schools. These include the integration of new attitudes and behavior from the executives to simple members.

\section{References}

[1] Handerson, A.T. (1987) The Evidence Continues to Grow: Parent Involvement Improves Student Achievement. National Committee for Citizens in Education, Columbia.

[2] Jeynes, W.H. (2003) A Meta-Analysis: The Effects of Parental Involvement on Minority Children’s Academic Achievement. Education and Urban Society, 35, 202-218. http://dx.doi.org/10.1177/0013124502239392

[3] Abdullahi, S.U. (1996) Parent Teacher Association as an Instrument of Community Participation in Education. http://www.zeda.org.ng/agm/4th.pdf

[4] Oniyangi, S.A. (2008) Strategies for Promoting School and Community Relationship for Better Productivity. In D.O.

[5] Hicks, B.W. (1992) Parents', Teachers’ and Students’ Perception of Effective Principals in Selected Middle Schools in South Carolina. Dissertation Abstracts International.

[6] Sammons, P., Hillman, J. and Mortimore, P. (1995) Key Characteristics of Effective Schools. A Review of School Effectiveness Research. Institute of Education, London.

[7] Cotton, K. and Wikelund, R.K. (2001) Parent Involvement in Education. http://www.nwrel.org/scpd/sirs/3/cu6ht 